\title{
Initial Application of Computer-Based Test as a Tool for Leaners' Learning Evaluation in The Industrial Revolution 4.0 Era
}

\author{
Petrus Dwi Ananto Pamungkas ${ }^{1}$, Robertus Koesmaryanto Oetomo ${ }^{2}$, Yakobus Suharyono $^{3}$, Uus \\ Rusmawan ${ }^{4}$, Hieronimus Erwin Indrawan ${ }^{5}$ \\ \{petrusananto@gmail.com ${ }^{1}, \underline{\text { koemaryanto@yahoo.com }}{ }^{2}, \underline{\text { info@ } @ \text { starki.id }^{3}}$, info@ binainsani.ac.id ${ }^{4}$, \\ kampus_d2@bsi.ac.id $\left.{ }^{5}\right\}$
}

\author{
${ }^{1}$ Secretary Department, STIKS Tarakanita, Kompleks Billy \& Moon, Pondok Kelapa, Jakarta 13450, \\ Indonesia \\ ${ }^{2,3}$ Communication Departement, ST IKS Tarakanita, Thamrin City Jakarta, Community Center Lt. 6, \\ Jalan. Thamrin Boulevard, Jakarta, Indonesia \\ ${ }^{4}$ Informatics Engineering, Universitas Bina Insani, Jalan Raya Siliwangi No. 6, Rawalumbu, Kota Bekasi \\ 17114, West Java, Indonesia, \\ ${ }^{5}$ Accounting Department, Universitas Bina Sarana Informatika, Jalan Margonda Raya No. 8, Pondok
} Cina, Depok 16424, West Java, Indonesia,

\begin{abstract}
Industrial Revolution 4.0 provides challenge, even more so, in the field of education. For the sake of the resources reduction and effectivity \& efficiency of learners' learning evaluation, ComputerBased Test provides its advantages to do so. This is an exploratory research using the experimental method. The experiment is applied in the use of Wondershare QuizCreator as a tool for leaners' learning evaluation. This research tries to deal with three critical questions: (a) what beneficial advantages does the CBT Wondershare QuizCreator provide in the learners' learning evaluation, (b) how is CBT Wondershare QuizCreator going to be applied to gain its effectiveness and efficiency, (c) is CBT Wondershare QuizCreator available to provide the test statistical validity and reliability. The result of the experiment in this research shows that inspite of the Industrial Revolution 4.0 challenge, pedagogy -based manipulations are needed in the application of CBT Wondershare QuizCreator to gain its powerful usage.
\end{abstract}

Keywords: Computer-Based, Test, Learning, Revolution, Industry

\begin{abstract}
1. Introduction
Rapid improvement of the technology creates changes amongst human activities es pecially on their daily activities. This phenomenon is widely understood as the ind ustrial revolution $4.0 \mathrm{on}$ which technology takes an important role in human lives. Being better technological literate, net generation characterizes this industrial revolution 4.0 era. This digital literacy, accompanied by the technological accessibility amongst human communities, makes technological much more accessible than ever. It is not the second or third priority of human lives anymore, moving to be the first need in human lives. Most, if it may be said, of human daily activities deal with technology. It is now being the core of human activities. Speed, accuracy, sources reduction and punctuality are the characteristics of effective activities conducted during the industrial revolution 4.0. Moreover, technological influences have already taken part in educational process.
\end{abstract}


E-learning has been commonly used in educationalsector. It's effectivity and efficiency make this e-learning activity conducted obligatorily. One consequent that follows is the online examination to access learners' acquisition of a certain competence requirement. Conventional examinations are still widely applied nowadays. It consumes lots of material such as paper, ink and some others. STIKS Tarakanita, as one of the educational institutions, are still applying this conventional method of assessing its leaners' competence acquisition. It consumes a lot of papers and ink, which are put into trash afterwards. It consumes spaces to store. When they become overload, the management takes the procedures of archives reductions. Consequently, it also consumes financial budgeting too. Summarizing this condition, the conventional examination process covers many chronological steps starting from examination process, test material duplication, examination process which involves many pers onnel, scoring process, archives storing management, and finally scoring process by the lecturers. It surely consumes much financial budgeting.

Computer Based Test (CBT) comes to be one alternative of learning as sessment. Computer Based Test (CBT) offers sources reduction. It offers fast and accurate report of learners' scoring system too.

Dealing with CBT Sekolah Tinggi Tarakanita (STARKI) Jakarta uses Computer Fixed Test (CFT) for the sake of its practiaclibility. The examination can be conducted at the same time for many groups of learners, but the questions of the examinations are manage din a such way that it will appear on screen randomly fromone students to another. It automaticaaly reduces the pos sibility amongst leaners to commit cheating during the examination. It accomodates more leaners to take the examination but it needs less proctors to be involved. Being part of the CBT, CFT provides real-time scores. This research applies the process of CBT in Basic Computer and Online Network (Komputer Das ar dan Jaringan Online). To deal with this CBT, the researchers use WonderShare QuizCreator, an computer application to create questions of the examination. The process of creating questions, executing the examination and the process of scoring are all taken in an internet-connected computers.

Academically, examination is the process of measuring learners' competence acquisition after a process of learning in a specified period of time by evaluating the learners' ability to ans wer the questions given correctly and appropriately and or to provide solutions towards artificial problems provided by the lecturers. It commonly measures intellectual competences of the learners [1].

Examination is usually conducted conventionally, meaning that leaners should come into certain rooms that have been provided for the purposes of the examination. Besides, it is also time consuming, personnel consuming because it needs proctors, sources consuming because it needs a lot of paper, ink \& other stationeries, and energy consuming because it involves a lot of people to handle. It also creates a big trash that need to be managed [2].

CBT is the online test and managed by internet-connected computer in the Supervisor mode. This model requires a supervisor to identify the Examinees and validate the process. Supervisor control the Examinee to login, control the process and confirm whether the Examinees have already taken the examination comprehensively [3]. There are four types of CBT form developed by ITC. (1) Open Mode CBT. It accommodates anyone without any supervision. It is openly and publicly accessible by anyone. Regis tration is not necessary. (2) 
Controlled Mode CBT. It accommodates anyone without any supervision. It is openly and publicly accessible by any one. Registration is obligatory by using the username and password. (3) Supervised Mode. It accommodates anyone with adminis trator. It is openly and publicly accessible by anyone, but username and password are required. The administrator is authorized to log the Examinees in and confirm whether the Examinees have taken the test comprehensively. (4) Managed ModeCBT. It is centralized online test. The authority defines and validate the test equipment's specification and performance. The authority als o provides training for any personnel involved in the process of the CBT.

Generally speaking, CBT is used to increase the efficiency and effectivity of the test administration. It is also hoped to increase the test validity and reliability. Reviewed from the side of the Examinees, CBT possibly motivates leaners to increase their academic performance. Lecturers are forced to create and prepare the examination to be more qualified and increase the measurability of the test [4].

Based on the adaptive algorithm and the characteris tics, there are eight models of the CBT. They are Computerized Fixed Test (CFT), Linear On The Fly Test (LOAF), Computerized Adaptive Test (CAT), A Stratified Computerized Adaptive Test (AS), Content Constrained CAT With ShadowTest, Testlet Based CAT, Multistage Computerized Mastery Test, Computer Adaptive Multistage Test [5].

Res earch doneby Vivi Pratiwi and Susantitried to create ICT-based learning evaluation tool by using Wondershare Quiz Creator. It proposed that qualified evaluation tool must meet some prerequisites and principles. It must be able to provide accurate data relevant to its functional purposes and measure the sample of certain behaviors. The research applied the system development model referring to ADDIE model (Analysis, Design, Develop, Implementation, Evaluation). The result proposed that Wondershare Quiz Creator is applicable significantly and positive responses from the learners are available [6].

Haida Dafitri's research tried to solve the problem caused by the undisciplined behavior of teachers to submit test material on time to the vice head master for the curriculum affairs, inefficient and ineffective time allocated for the test, the paper consuming test, learners' cheating habits and possibility and the time consuming of the scoring proces s which result in late submis sion of the leaners' scores towards. The research took place in SMA Harapan I Medan. This research applied survey, interviews and literature s tudies through articles, books and journals. The result showed that wondershare quiz creator helps the management of the school to conduct its entry selection test better and more effective and efficient [7].

Research conducted by Petrus Dwi Ananto Pamungkas, Harjunadi Wicaksono, dan Henri Septanto deals with how to ease and as ses selection test for the applicant of computer operator specified training. Prototyping method was used to create multimedia-based test selection creator application. The res ult showed that the multimedia-based selection test is less time and sources consuming and provided real time score.[8].

\section{Research Methods}

This research applies experiment and trial initial application of the CBT in a conditioned classroom. The research was conducted in computer laboratory of Sekolah Tinggi Tarakanita (STARKI) Jakarta. In relation to the CBT, the research uses WonderShare Quiz Creator. The 
subject used for this research is Basic Computer and Online Network (Komputer Dasar dan Jaring an Online) The datawere collected from the online preparation test simulation and the real test, liturature studies through online articles, journaland books. The analysis was done afterwards.

\section{The Result and the Analysis}

\subsection{Use Case Diagram Computer Based Test (CBT) in Sekolah Tinggi Tarakanita (STARKI)}

Figure 1 describes the learners, lecturers and board of management involvement in the application of WonderShare Quiz Creator in Sekolah Tinggi Tarakanita (STARKI). The lectures created test material directly on the computer application or indirectly by typing the test material first, and operator helped them input them into the computer application. Learners log themin and did the test. Head of the Study Program received the result of the test afterwards.

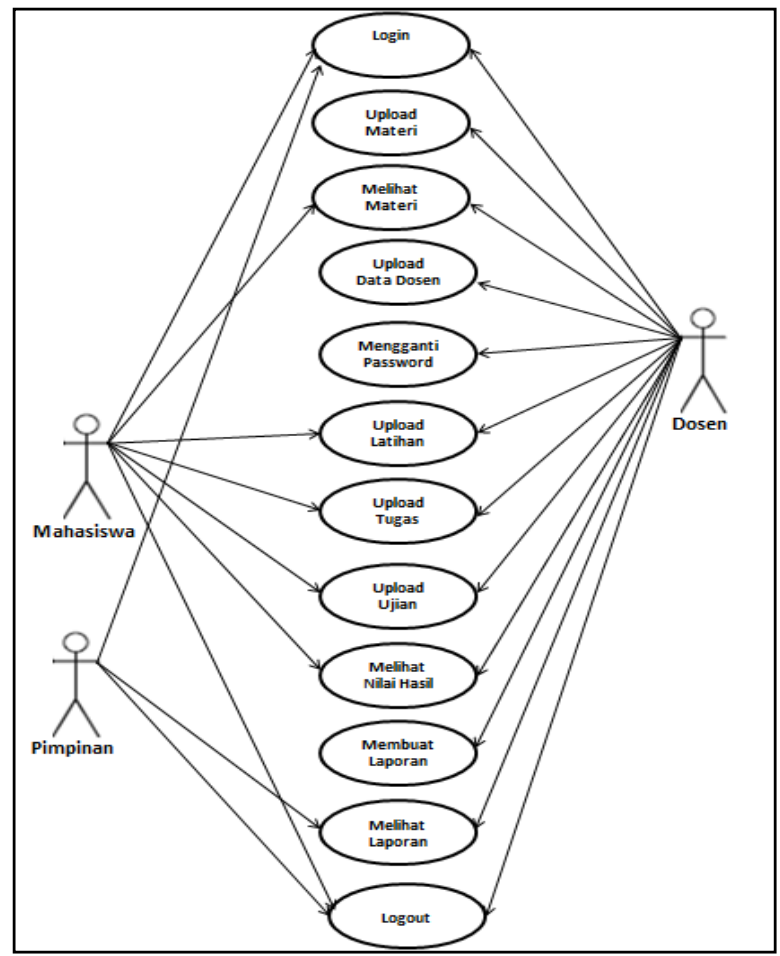

Picture 1. Use Case Application Diagram

\subsection{Initial Preview of the WonderShare Quiz Creator}

This intial preview gives the opportunity to Examinees to choose type of the test. 


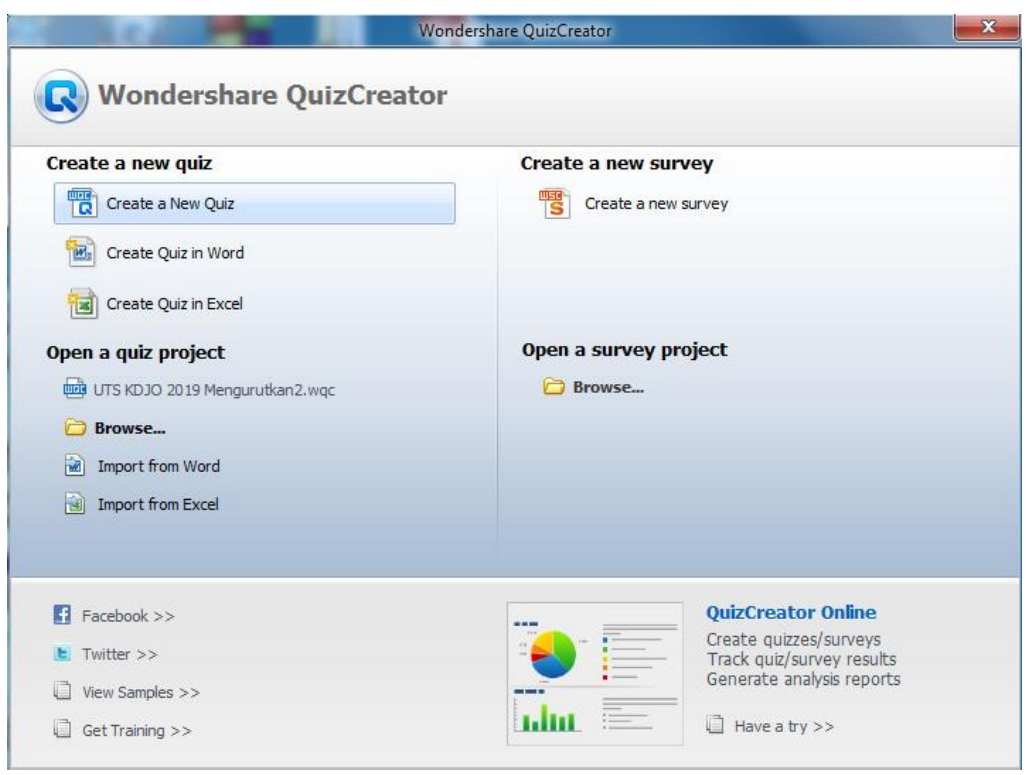

Figure 2. Initial Preview of the WonderShare Quiz Creator

\subsection{Preview of the Type of the Test}

This screen displays the test material. This can take in the formof objective tests such as True or False, Simple and Complex Multiple Choices, Gap Filling, Sorting, Matching and some others.

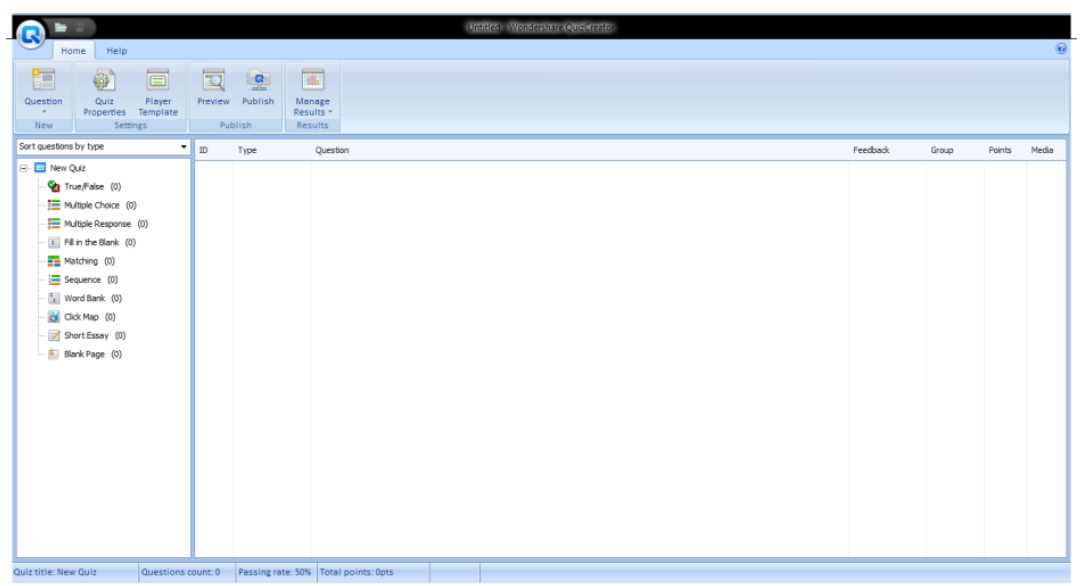

Figure 3. Preview of the type of the test

\subsection{Preview of the Ready-to-use- Test}

This screen displays the information of the ready-to-use-test. The display of number of questions and type of questions are available. 


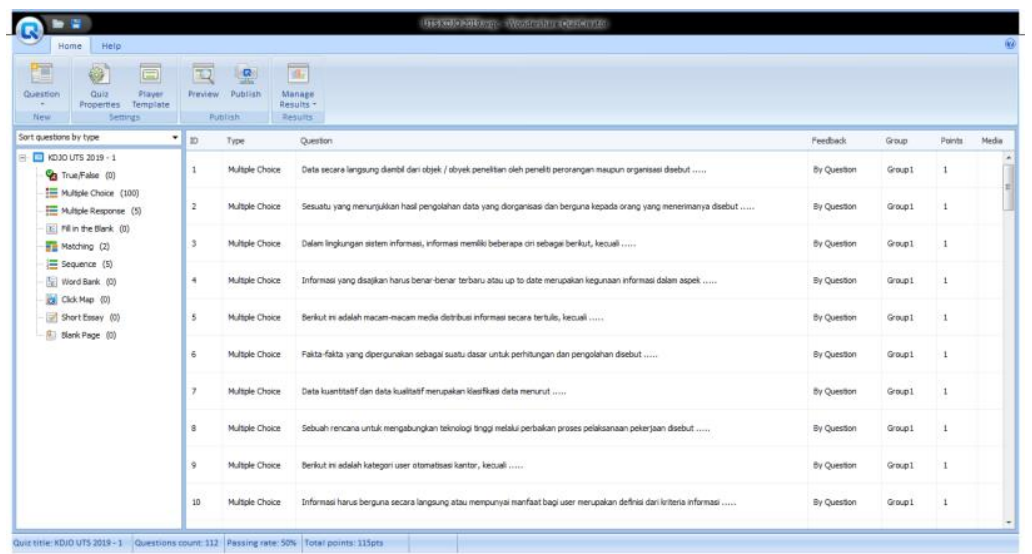

Figure 4. Preview of the Ready-to-use-Test

3.5 Preview of the Login

This screen provides the coloumn for the examinees to input her identity

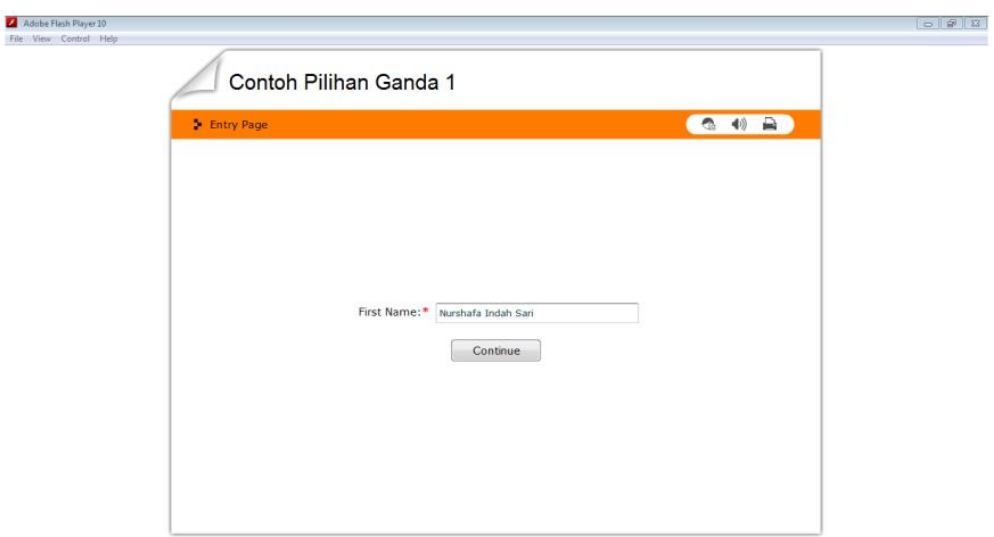

Figure 5. Preview of the Login

\subsection{Preview of the Test Material}

This preview dis plays test material. It covers the number of the test material, time provided to ans wer the questions, the questions, choices of the asnwer, chosen answer, scrolling buttons. 


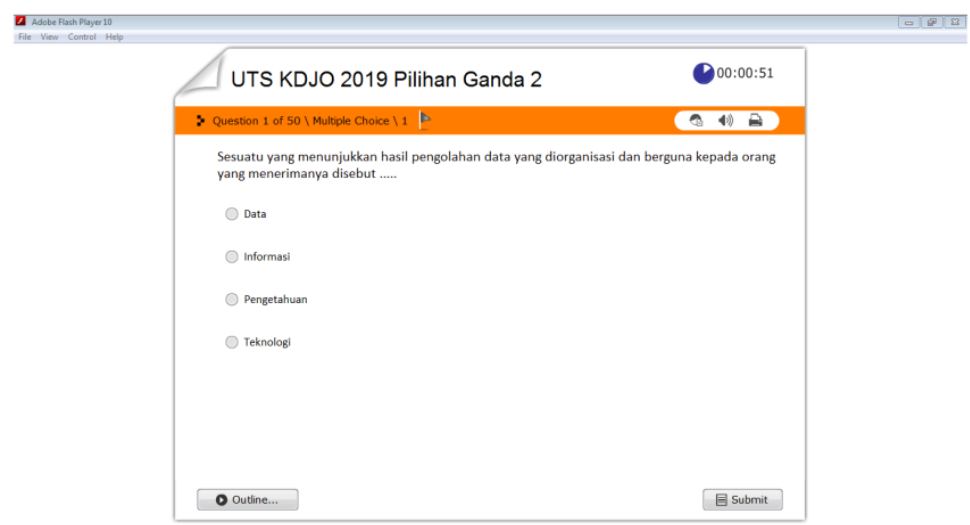

Figure 6. Preview of the Test Material

\subsection{Preview of the Correct Answer}

This preview informs whether the answer has been chosen is correct. The correct answer is indicated.

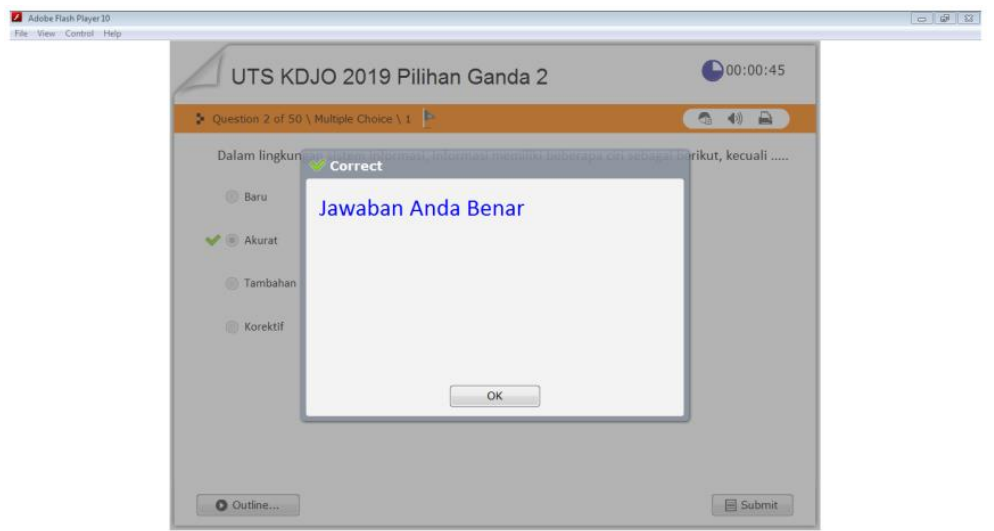

Figure 7. Preview of the Correct Answer

\subsection{Preview of the Incorrect Ans wer}

This preview informas whether the answert has been chosen is incorrect. The incorrect answer is indicated. 


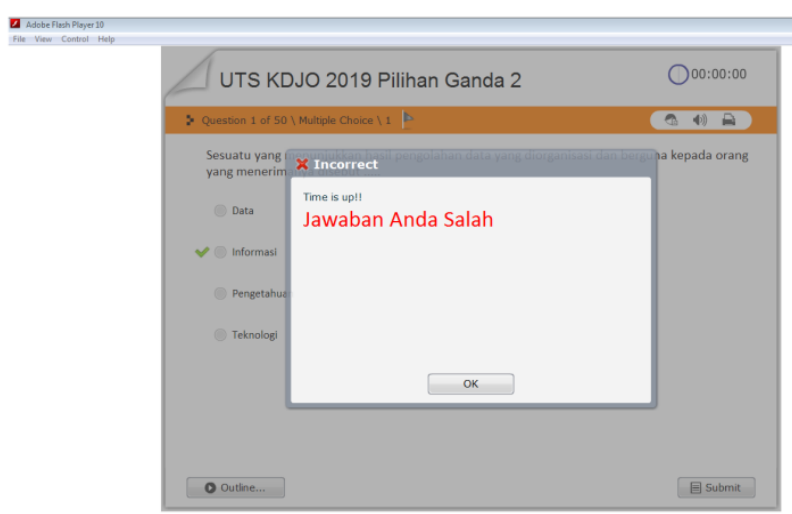

Figure 8. Preview of the Incorrect Answer

\subsection{Preview of the Result}

This preview informas the score obtained by th examinee, the level of the passing grades and the time consummed to finish the test.

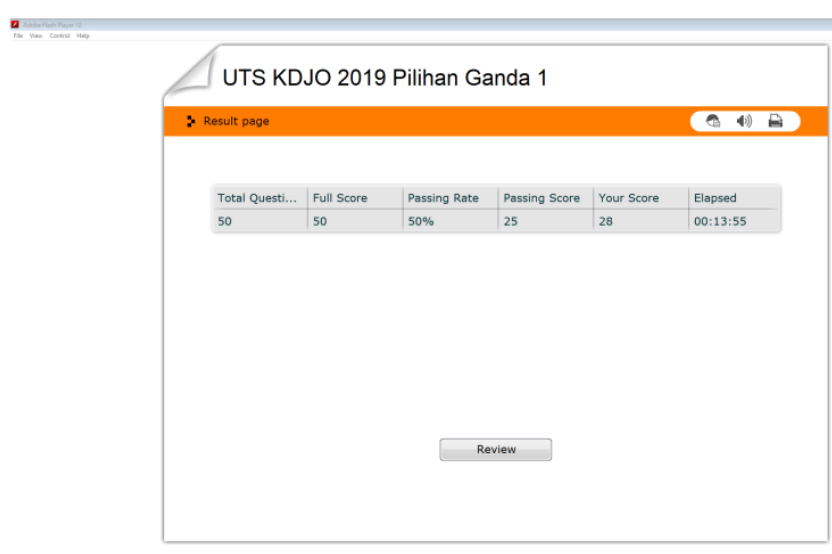

Figure 9. Preview of the Result

\subsection{Black Box Testing}

Black Box examines :

Table 1. Needs to be tested

\begin{tabular}{ll}
\hline \multicolumn{1}{c}{ Needs to be tested } & \multicolumn{1}{c}{ Test Element } \\
\hline WonderShare QuizCreator Installation & Preview of the application on computer \\
Test Question Creation & Managing time and Choosing type of test \\
Figure Insertion & Preview of the Figure of the test \\
Copy of test file into computer & Preview of the test file on screen \\
Executing test file & Executing test file .exe \\
Login & Validate login \\
Submit & Preview Correct and incorrect answer \\
Finish & Preview the score of the test result \\
\hline
\end{tabular}


Table 2. Test Scenario and the Result

\begin{tabular}{|c|c|c|c|}
\hline Requirement & Test Scenario & Expected Result & Test Result \\
\hline \multirow{2}{*}{$\begin{array}{l}\text { Application } \\
\text { Installation }\end{array}$} & \multirow{2}{*}{$\begin{array}{c}\text { Installing WonderShare Quiz } \\
\text { Creator }\end{array}$} & $\begin{array}{l}\text { Dis playing Preview of } \\
\text { the shortcut of the } \\
\text { application on desktop }\end{array}$ & Successful \\
\hline & & $\begin{array}{l}\text { Dis playing Preview of } \\
\text { the Opening }\end{array}$ & Successful \\
\hline \multirow{3}{*}{ Question Creation } & $\begin{array}{l}\text { Create Objective Test } \\
\text { Simple Multiple Choices }\end{array}$ & $\begin{array}{l}\text { Displaying Preview of the } \\
\text { Objective Test Simple } \\
\text { Multiple Choices }\end{array}$ & Successful \\
\hline & $\begin{array}{l}\text { Create Objective Test } \\
\text { Complex Multiple Choices }\end{array}$ & $\begin{array}{l}\text { Displaying Preview of } \\
\text { Objective TestComplex } \\
\text { Multiple Choices }\end{array}$ & Successful \\
\hline & $\begin{array}{l}\text { Create Objective Test } \\
\text { Complex Multiple Choices }\end{array}$ & $\begin{array}{l}\text { Displaying Preview Objective } \\
\text { Test Complex Multiple } \\
\text { Choices }\end{array}$ & Successful \\
\hline Figure Insertion & Insert Figure & Displaying Preview of the & Successful \\
\hline $\begin{array}{l}\text { Test File } \\
\text { Distribution }\end{array}$ & $\begin{array}{l}\text { Copy test file .exe into } \\
\text { examinees' computers }\end{array}$ & $\begin{array}{l}\text { Displaying Preview of the } \\
\text { shortcut of the application on } \\
\text { desktop }\end{array}$ & Successful \\
\hline $\begin{array}{l}\text { Executing Test } \\
\text { File }\end{array}$ & Executing test file .exe & $\begin{array}{l}\text { Displaying Preview of the } \\
\text { login }\end{array}$ & Successful \\
\hline Login Name & Input Name of the Examinee & $\begin{array}{l}\text { Displaying Preview of the } \\
\text { general instructions }\end{array}$ & Successful \\
\hline \multirow{2}{*}{ Answering } & \multirow{2}{*}{$\begin{array}{l}\text { Ans wering and push submit } \\
\text { button }\end{array}$} & $\begin{array}{l}\text { Displaying Preview of } \\
\text { "Correct Answer" }\end{array}$ & Successful \\
\hline & & $\begin{array}{l}\text { Displaying Preview of } \\
\text { "Incorrect Answer" }\end{array}$ & Successful \\
\hline Finishing the Test & Push finish button & $\begin{array}{l}\text { Displaying Preview of the test } \\
\text { score }\end{array}$ & Successful \\
\hline
\end{tabular}




\section{Conclusion}

The result of the initial application of WonderShare Quiz Creator in Sekolah Tinggi Tarakanita (STARKI) shows that the use of CBT eases the process of the learners' assessments. The speed and the accuracy of the result taken by the application proposes the strength of this application. Besides, the application is also applicable for test preparations: the researchers were able to analyzes the validity and the reliability of the test questions based the numbers of the correct and incorrect answers. He examinees can also take its advantage by reviewing the questions they have done based on the correct and the incorrect answer they have chosen. The last, the use of this CBT application is surely less time, energy and sources consuming.

\section{Acknowledgements}

We would like to thank the Department of Secretary and the Department of Communication, Tarakanita School of Communication \& Secretary (STARKI) for their support and opportunity given to us to attend the International Joint Conference on Science, Engineering and Technology (IJCSET). We hope that our paper can enrich readers' knowledge. Our sincere gratitude goes to thereviewers who have given us valuable input to make our paper better and worth-published.

\section{References}

[1] B. Tynan, Melatih Anak Berpikir Seperti Jenius. Jakarta: PT Gramedia Pustaka Utama, 2004.

[2] H. Sutopo, "Pengembangan Evaluasi Pembelajaran Berbasis Multimedia dengan Flash, PHP, dan MySQL," J. Inform., vol. 10, no. 2, pp. 56-65, 2009.

[3] D. Batram and et.al., Computer-Based Testing and the Internet. USA: University of Massachusetts at Amherst, 2001.

[4] C. Redecker, The Use of ICT for the Assessment of Key Competences. Luxembourg: Publication Office of the European Union, 2013.

[5] R. M. Luecht and S. G. Sireci, A Review of Models for Computer-Based Testing. New York: The College Board, 2011.

[6] V. Pratiwi and Susanti, "Pengembangan Alat Evaluasi Pembelajaran Berbasis ICT Menggunakan Wondershare Quiz Creator Pada Materi Penyusutan Aset T etap," J. Pendidik., vol. 4, no. 1, pp. 17, 2016.

[7] H. Dafitri, "Pemanfaatan Wondershare Quiz Creator Dalam Tes Berbasis Komputer," QUERY J. Sist. Inf., vol. 1, no. 1, pp. 8-18, 2017.

[8] P. D. A. Pamungkas, H. Wicaksono, and H. Septanto, "Aplikasi Soal Ujian Seleksi Peserta Pelatihan Kejuruan Operator Komputer Berbasis Multimedia Untuk Mendukung Konsep Paperless Office Di PPKD Jakarta Timur,” Bina Insa. ICT J., vol. 2, no. 1, pp. 63-74, 2015. 